Supporting information

\title{
Tuned Polymer Electrolyte Membranes Based on Aromatic Polyethers for Fuel Cell Applications
}

Kenji Miyatake, Yohei Chikashige, Eiji Higuchi, and Masahiro Watanabe*

Clean Energy Research Center, University of Yamanashi,

4 Takeda, Kofu 400-8510, Japan

E-mail: m-watanabe@yamanashi.ac.jp 
(a)

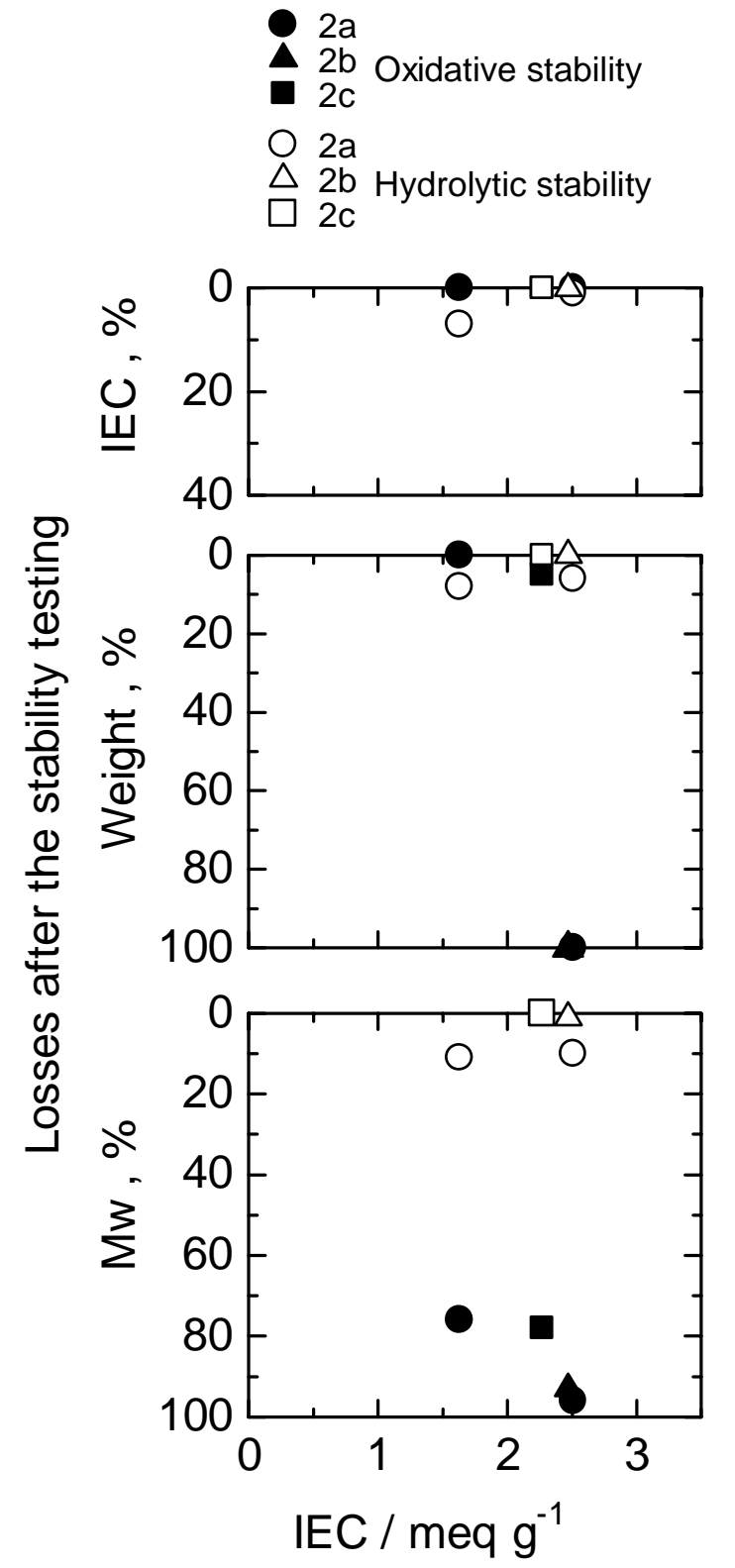

(b)
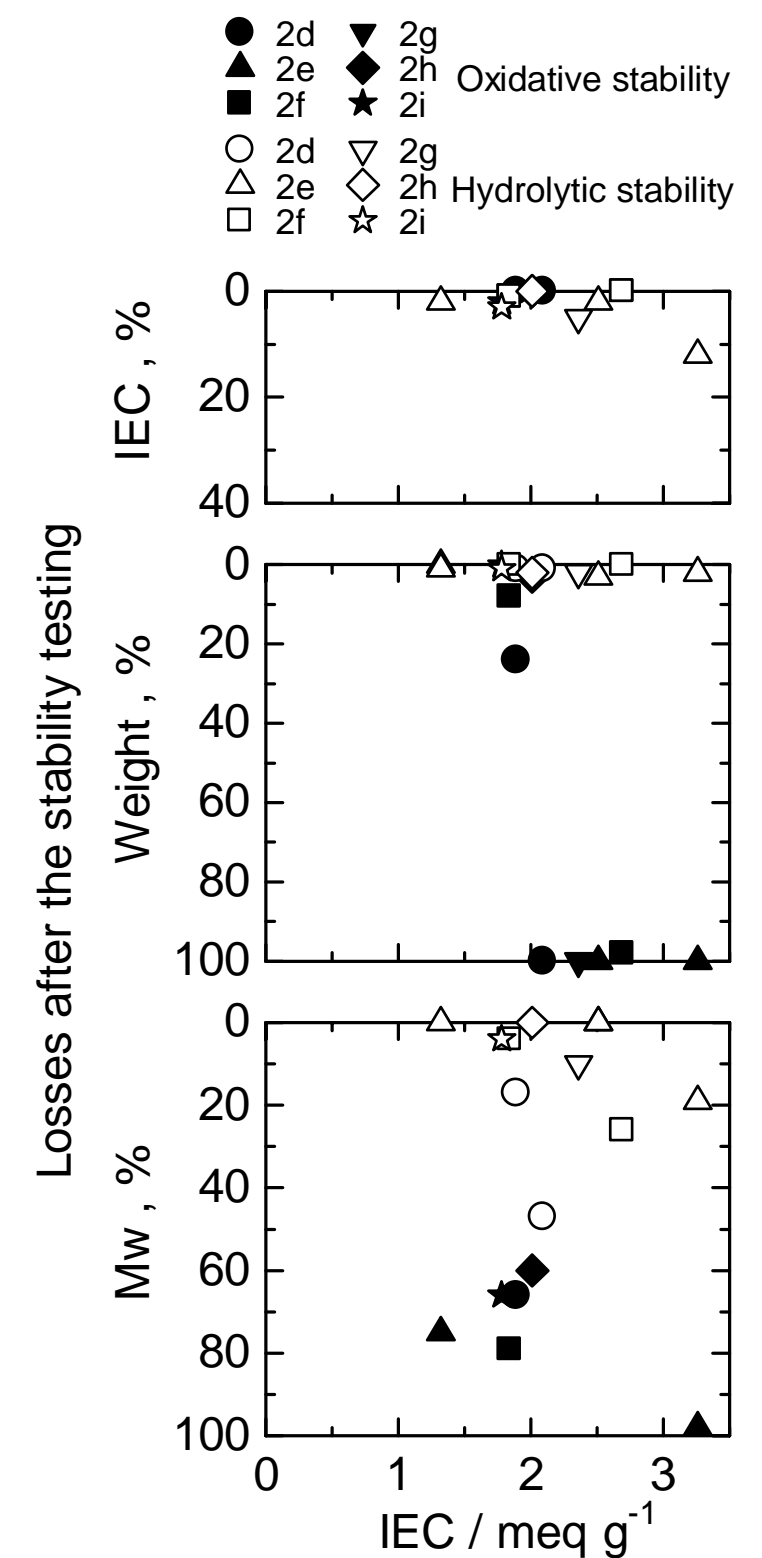

Figure S1. Losses of IEC, weight and molecular weight of $\mathbf{2 a - i}$ membranes after oxidative and hydrolytic stability tests; (a) homopolymers $\mathbf{2 a - c}$ and (b) copolymers $\mathbf{2 d - i}$. 


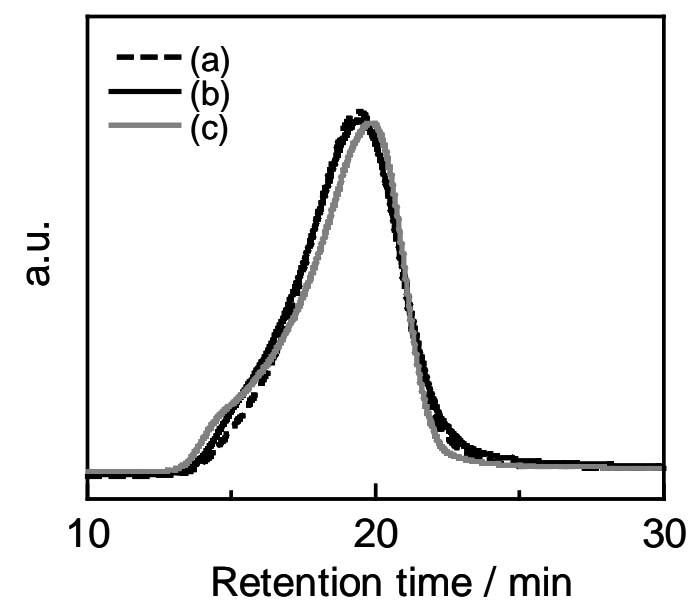

Figure S2. Elution curves of gel permeation chromatograms of (a) $2 \mathbf{e}$ (IEC = $3.26 \mathrm{meq} / \mathrm{g}$ ), (b) $\mathbf{2 e - 1 0 0}$ (IEC = $3.26 \mathrm{meq} / \mathrm{g}$ ) after durability test at $100{ }^{\circ} \mathrm{C}$ and $80 \% \mathrm{RH}$ for $10,000 \mathrm{~h}$, and (c) $\mathbf{2 e - 1 2 0}$ (IEC $=3.26 \mathrm{meq} / \mathrm{g}$ ) after durability test at $120^{\circ} \mathrm{C}$ and $40 \% \mathrm{RH}$ for $10,000 \mathrm{~h}$.

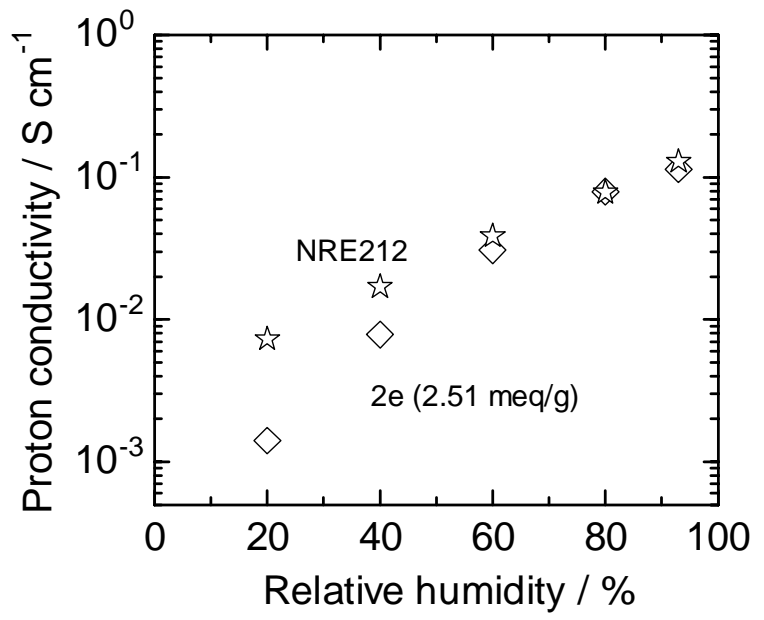

Figure S3. Humidity dependence of the proton conductivity of $2 \mathrm{e}(2.51 \mathrm{meq} / \mathrm{g})$ and Nafion NRE 212 membranes at $90{ }^{\circ} \mathrm{C}$. 


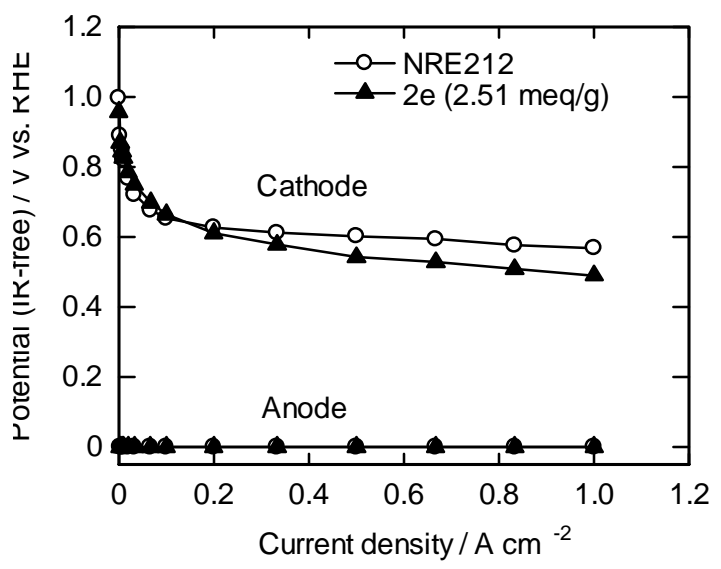

Figure S4. Steady-state current potential curves of fuel cells at low humidity conditions for 2e (A) and Nafion (०) membranes. All cells were operated at $90{ }^{\circ} \mathrm{C}$. Potentials were corrected by ohmic resistance measured with a current interrupter.

Table S1. Glass Transition Temperature of Polymers.

\begin{tabular}{cc}
\hline polymer & $T_{\mathrm{g}}\left({ }^{\circ} \mathrm{C}\right)$ \\
\hline 1a & 282 \\
1c & 311 \\
1d & 245 \\
1e & 264 \\
\hline
\end{tabular}

